POLITEJA

nr 1(58), 2019, s. 31-45

https://doi.org/10.12797/Politeja.16.2019.58.03

\author{
Wojciech BEDYŃSKI \\ Uniwersytet Warszawski \\ w.bedynski@uw.edu.pl
}

\title{
LIMINALNOŚĆ KRAJOBRAZU KULTUROWEGO
}

\section{ABSTRACT Liminality of the Cultural Landscape}

According to Tim Ingold ${ }^{1}$, cultural landscape is not "land” nor „space”, but is a dweller's narration on the reality that surrounds him or her. This narration is in permanent process, it grows with the society that lives in a certain place, parts of it die with the people that pass away. Although it is subject to individual reception, some narrations are shared by many. Therefore it is both personal and social phenomenon. This narrative landscape is full of borders and spheres that are built on symbolic values of places and objects. In traditional societies it has been well visible - one could easily distinct the narration of the forest from the narration of the village. In the modern world the landscape has gone through a major transformation, nonetheless it kept crucial mechanisms of its construction. Contemporary multi-sited landscapes or virtual landscapes also contain borders and spheres, are individual and shared by many. This article presents recent changes in the approach to the liminality of the cultural landscape, differences that were experienced when passing from traditional to modern society. This change is particularly visible when comparing generations: new global generation (generation $\mathrm{Y}$, generation $\mathrm{Z}$ ) has a different experience of the landscape than generation of their parents and grandparents - who had grown in a still local and territorially defined places. But new landscapes do have borders and spheres, however their shape may be slightly different.

Keywords: cultural landscape, multi-sited ethnography, migration

Słowa kluczowe: krajobraz kulturowy, etnografia wielostanowiskowa, migracja

T. Ingold, The Temporality of the Landscape, „World Archeology” 1993, vol. 25, nr 2, s. 153. 
leksander Sołżenicyn, rozpoczynając swój Archipelag GUŁag, pisze, że każdy z nas
jest osia świata. Każdy człowiek, jako odrębny podmiot, organizuje sobie kosmos i znów cytując Sołżenicyna - wszechświat ma tyle punktów centralnych, ile w nim żywych istot ${ }^{2}$. Człowiek zawsze stawia siebie w centrum rzeczywistości, choćby poprzez fakt, że interpretuje ją i racjonalizuje, posługując się własnym umysłem ${ }^{3}$. Każda jednostka w procesie wychowania poznaje otaczający świat, przypisuje poszczególnym poznanym miejscom i przestrzeniom pewne treści kulturowe („narracje”) i włącza je do własnego krajobrazu kulturowego. Oczywiście niektóre treści będą zbieżne z krajobrazem kulturowym innych ludzi, co sprawia, że fenomen ten ma wymiar zarówno indywidualny, jak i społeczny.

Symboliczna organizacja krajobrazu kulturowego, będąca niezwykle ważnym czynnikiem w procesie enkulturacji, polega w dużej mierze na wyznaczeniu granic między poszczególnymi sferami różniącymi się jakościowo od siebie. Te granice mogą, acz nie muszą, pokrywać się z fizycznymi granicami w przestrzeni. Krajobraz kulturowy jest zbiorem niewidzialnych granic i „punktów światła”, jego liminalność ma wpływ na symboliczne tworzenie kosmosu.

\section{KRAJOBRAZ KULTUROWY}

Krajobraz kulturowy, cytując Beatę Frydryczak, wpisuje się w waską szczeline pomiędzy kulturą a naturą . Nie może być opisany przez prostą dychotomię, która z jednej strony tłumaczy go jako naturalne (przyrodnicze) tło ludzkich aktywności - jak chce potoczne rozumienie; a z drugiej strony jako próbę kognitywnej i symbolicznej organizacji przestrzeni - jak chce nowoczesne, postmodernistyczne podejście w humanistyce. Tim Ingold proponuje trzecie rozumienie, pośrednie: krajobraz kulturowy jest tym, co według niego można nazwać „perspektywą mieszkańca” (dwelling perspective $)^{5}$ - krajobraz byłby zatem otoczeniem poznawanym i przekształcanym przez człowieka w procesie enkulturacji, powolnego integrowania się z nim poprzez zamieszkiwanie w danym miejscu. Stratygrafia krajobrazu kulturowego ukazuje poszczególne jego warstwy będące dziełem różnych społeczności, które na przestrzeni czasu historycznego zamieszkiwały dany obszar ${ }^{6}$. Krajobraz jest fizycznym i symbolicznym świadectwem życia tych społeczności poprzez pokolenia, wyrazem całokształtu ludzkich działań, ale jest też stale tworzony na nowo przez ludzi - nigdy nie jest „skończony”, zawsze „w procesie”. Pamięć krajobrazu jest zatem historią „długiego trwania”", świadectwem pamięci zbiorowej kształtowanym przez Człowieka jako gatunek ${ }^{8}$.

2 A. Sołżenicyn, Archipelag GUŁag 1918-1956, przeł. J. Pomianowski, Poznań 2008, s. 7.

Por. M. Eliade, Sacrum i profanum. O istocie religijności, przel. R. Reszke, Kraków 1996, s. 34.

B. Frydryczak, O zakotwiczeniu krajobrazu w kulturze, „Prace Kulturoznawcze” 2013, t. 15, s. 161.

T. Ingold, The Temporality..., s. 152.

U. Myga-Piątek, Pamięć krajobrazu - zapis dziejów w przestrzeni, „Studia Geohistorica” 2015, nr 3, s. 37.

Określenia tego użył Fernand Braudel w książce Morze Śródziemne i świat śródziemnomorski w epoce Filipa II, przeł. M. Ochab i T. Mrówczyński, Gdańsk 1976, s. 20-25.

8 U. Myga-Piątek, Pamięć krajobrazu..., s. 34. Por. J. Assman, Communicative and Cultural Memory, 
Jako taki krajobraz kulturowy ma charakter zarówno indywidualny, jak i społeczny. $\mathrm{Z}$ jednej strony jest przypisany jednostce i nie ma dwóch takich samych krajobrazów (gdyż jego indywidualny odbiór jest uwarunkowany przez osobiste doświadczenia jednostki, jej pamięć i biografię); z drugiej strony pewne punkty czy cechy tego krajobrazu są współdzielone społecznie i zależą od procesów socjalizacyjnych w danej społeczności (zwłaszcza we wczesnym okresie życia). Przykładem tego ${ }^{9}$ może być las: kiedy lokalnego mieszkańca postawimy na skraju lasu, zobaczy drzewa. Spośród tych drzew niektóre będą miały dla niego znaczenie symboliczne (np. miał tam w dzieciństwie domek na drzewie; pochował pod nim psa itp.). Takie punkty w krajobrazie, które mają znaczenie symboliczne (znów: w wymiarze indywidualnym bądź społecznym), można nazwać „punktami światła”, ponieważ wyraźnie zaznaczają się na tle innych, symbolicznie mniej ważnych miejsc i obiektów. Dla obcego (np. turysty) wszystkie drzewa w lesie będą jakościowo takie same, nie będzie więc dostrzegał on „punktów światła”.

Krajobraz u Ingolda jest różny od przestrzeni, ponieważ jest heterogeniczny i jakościowy, a nie homogeniczny i ilościowy ${ }^{10}$. Wracając do przykładu lasu: dla osoby „spoza” przestrzeń będą stanowić po prostu hektary drzew, które jakościowo się od siebie nie różnią. „Miejscowy” będzie mógł wyróżnić nie tylko poszczególne drzewa, które jakościowo będą inne, ale całe obszary tego lasu, które są z różnych względów odmienne (np. kiedyś stanowiły część majątku ziemskiego; należą do innej gminy). Krajobraz, w odróżnieniu od przestrzeni, jest zatem pełen jaśniejszych i ciemniejszych punktów, sfer, połączeń, granic. Również czas i odległość podlegają tutaj subiektywizacji i indywidualnemu doświadczaniu.

Niezwykle istotną cechą krajobrazu kulturowego jest kwestia narracji. Krajobraz, jak zauważa Meining ${ }^{11}$, można „czytać” jak książkę - poszczególne miejsca i obiekty coś nam opowiadają, chociaż często potrzebujemy interpretatora. Te narracje dotyczą czy raczej są udziałem również ludzi, którzy żyli w przeszłości i współtworzyli ten krajobraz, który teraz nas otacza. Archeolog widzi przeszłość nie tylko pod ziemią, ale również na powierzchni - drzewa, rowy, budynki, pagórki i drogi są nośnikami pamięci. Pojęcie krajobrazu jest zatem silnie związane właśnie z pojęciem pamięci (indywidualnej i społecznej). Zdaniem Ingolda obserwowanie krajobrazu jest każdorazowo aktem przywoływania pamięci ${ }^{12}$.

Doskonałym przykładem związku tych narracji z krajobrazem kulturowym są mity w społeczeństwach pierwotnych. Aborygen, chodząc po ziemiach przodków, odtwarza mity, które w dodatku tłumaczą, dlaczego robi to, co robi. Andrzej Szyjewski pisze, że słowo djalkiri w językach Aborygenów australijskich oznacza „stopy”. Nie chodzi jednak o część ciała, a raczej o „ślady stóp” odciśnięte w krajobrazie przez przodków ${ }^{13}$. To

[w:] Cultural Memory Studies: an International and Interdisciplinary Handbook, red. A. Erll, A. Nünning. Berlin-New York 2008.

9 Przykład mój-W.B.

10 T. Ingold, The Temporality..., s. 154.

11 D.W. Meining, The Interpretation of Ordinary Landscapes, New York 1979, s. 11.

12 T. Ingold, The Temporality..., s. 168.

13 A. Szyjewski, Mitologia australijska jako nośnik tożsamości, Kraków 2014, s. 21. 
pojęcie współistnieje z innym hasłem, songlines, „ścieżki śpiewu” - jest to przy okazji tytuł głośnej książki Bruce’a Chatwina z 1987 r. ${ }^{14}$ Plemiona koczownicze mają trasy swoich wędrówek nie tylko opisane mitami, ale także przez te mity symbolicznie wytłumaczone. Krajobraz jest częścią nas, podobnie jak my jesteśmy częścią krajobrazu.

By lepiej zobrazować, czym jest krajobraz kulturowy w odniesieniu do świata fizycznego, Ingold powołuje się na teorię lingwistyczną Ferdinanda de Saussure'a ${ }^{15}$. Podobnie jak u szwajcarskiego lingwisty, tak i w badaniach nad krajobrazem kulturowym można się posłużyć metaforą kartki papieru - po jednej stronie jest 'znaczone' (u de Saussure'a signifié), po drugiej stronie 'znaczące' (signifiant). Słowo (dźwięk), które samo w sobie nic nie znaczy, odpowiada pojęciu. W przypadku krajobrazu kulturowego ta warstwa symboliczna i narracyjna odpowiada danemu odcinkowi powierzchni ziemi.

Krajobraz można traktować jako źródło historyczne - ponieważ daje się z niego wyczytać nie tylko pozostałości materialne po minionych pokoleniach, ich wojnach, sztuce, codziennych czynnościach, ale także całą warstwę narracji oraz symboliki. Krajobraz jest wyrazem kontekstu zabytku, a nie tylko jego materii ${ }^{16}$.

Oprócz kategorii krajobrazu, rozumianej jako związek człowieka z otoczeniem wraz z całą gamą symbolicznych relacji, które za tym stoją, Ingold wprowadza pojęcie taskscape, jako przestrzeni codziennych czynności wpisanych w kontekst krajobrazu kulturowego ${ }^{17}$.

Taskscape jest związkiem krajobrazu z czasem: opisuje nie tylko relację człowieka $\mathrm{z}$ otoczeniem, ale też wpisuje ją w kontekst temporalny. W tradycyjnym społeczeństwie pewne miejsca i sfery były powiązane z rocznym cyklem prac na roli, cyklem życia jednostki i społeczności, kalendarzem świątecznym. Praca, podobnie jak przestrzeń, jest policzalna i homogeniczna - można policzyć czas spędzony na wykonywaniu danej czynności; jednocześnie człowiek ma ograniczoną ilość czasu, który może przeznaczyć na określone czynności (tasks). Czas, poprzez jego znaczenie w życiu człowieka, jest czynnikiem, który definiuje wartość poszczególnych elementów krajobrazu. To właśnie czas spędzony w danym miejscu (np. w domu rodzinnym, szkole) jest powodem, dla którego czujemy sentyment do danego miejsca, dla którego wartościujemy je bardziej od innych fragmentów przestrzeni, a więc czynimy naszym „punktem światła". Czas wyznacza też granice ${ }^{18}$. Nie chodzi tu o czas astronomiczny, który jest de facto sztucznym, pozaludzkim pojęciem, lecz o czas społeczny ${ }^{19}$. Czas społeczny

14 B. Chatwin, The Songlines, London 1987. Książka wzbudziła swego czasu bardzo rozbieżne reakcje krytyków - dla jednych będąc „odkryciem” związków kulturowych pomiędzy różnymi plemionami koczowniczymi świata, a nawet próbą sięgnięcia w najstarszą warstwę kultury ludzkiej, dla innych postkolonialnym, europocentrycznym spojrzeniem na Aborygenów australijskich.

15 T. Ingold, The Temporality..., s. 155. Por. F. de Saussure, Kurs jezzykoznawstwa ogólnego, przeł. K. Kasprzyk, wstęp. W. Doroszewski, Warszawa 1961.

16 Wyrazem rosnącej świadomości znaczenia narracji w kulturze jest konwencja UNESCO w sprawie ochrony niematerialnego dziedzictwa kulturowego z 2003 r. (Dz. U. z 2003 r., Nr 172, poz. 1018).

17 T. Ingold, The Temporality..., s. 153.

18 Np. czas, który trzeba poświęcić na dojazd, stanowi granicę między tym, co „blisko”, a tym, co „daleko”.

19 Prekursorem tego pojęcia był Emil Durkheim - Opodziale pracyspotecznej, przeł. K. Wakar, Warszawa 
wyznacza nam w ramach znanego krajobrazu rytm codziennych zajęć, świąt, a także wyjątkowych wydarzeń. Bardzo często jest cykliczny, powtarzalny, doświadczany subiektywnie i chętnie wymyka się linearnej chronologii.

Taskscape jest zjawiskiem społecznym, ponieważ poszczególne aktywności ludzkie (tasks) nachodzą na siebie przestrzennie i czasowo. Jest też tym punktem, gdzie rytm życia człowieka styka się z rytmem życia przyrody. Organizacja prac i zadań była i jest dopasowana do wschodów i zachodów Słońca, pór roku, pływów morskich itp.

\section{GRANICE W KRAJOBRAZIE}

W tak zdefiniowanym krajobrazie kulturowym granice - te widzialne i te niewidzialne - mają pierwszorzędne znaczenie dla organizacji symbolicznej. W indywidualnej i zbiorowej percepcji krajobrazu kulturowego poszczególne sfery różnią się od siebie jakościowo. Przejście z jednej sfery do drugiej, a zatem przekroczenie granicy, jest więc czymś więcej niż przekroczeniem progu czy miedzy lub też wejściem z pola w las - jest wejściem do zupełnie nowej rzeczywistości, a czasem nawet do innego świata.

Jacques Le Goff, w fundamentalnym dla mediewistyki dziele Kultura średniowiecznej Europy (wyd. polskie Warszawa 1970), w rozdziale o strukturach przestrzennych i czasowych pisze, że jedną z podstawowych kategorii w literaturze i kulturze europejskiego Średniowiecza jest granica las-polana ${ }^{20}$. W Europie, gdzie ogromną większość obszaru zajmowała wtedy wielka puszcza, polana, na której stała wieś, jawiła się jako wyspa cywilizacji pośród niebezpiecznego morza drzew. Polana oznaczała bezpieczeństwo, domenę człowieka, dobrobyt uzyskany ciężką pracą. Była także miejscem sacrum, stał na niej budynek kościoła. Las z kolei kojarzył się z niebezpieczeństwem, przygodą, awanturnictwem, pogańską magią. Symbolizował dziką naturę, która z jednej strony pociągała, ale z drugiej strony była niebezpieczna; podczas gdy polana oznaczała kulturę - czasem nudną i naznaczoną ciężką pracą, ale za to bezpieczną i znaną. Przygody $\mathrm{w}$ romansach rycerskich z reguły mają miejsce w lesie. Tę symbolikę, wpisaną głęboko w tradycję europejską, dobrze oddaje film Osada (oryg. The Village) z 2004 r.

Sama granica miała i ma w kulturze bogatą warstwę znaczeniową i pełniła ważną funkcję w krajobrazie kulturowym. Granica, jako „ziemia niczyja” (no man's land), jest poniekąd zawieszona pomiędzy dwiema rzeczywistościami - symbolicznie oddziela nie tylko samą przestrzeń, lecz także dwie różne rzeczywistości, a czasem nawet dwa różne światy. Taką rolę pełnił próg domu - jako granica pomiędzy przestrzenią rodzinną, bezpieczną, domową, a przestrzenią społeczną - orbis interior i orbis exterior $^{21}$; a także np. mur cmentarza - jako granica pomiędzy światem żywych a światem

2011. Por. T. Banaszczyk, Czas jako kategoria spoteczna: wstępne rozważania socjologiczne o czasie, Wrocław 1981.

20 J. Le Goff, Kultura średniowiecznej Europy, przeł. H. Szumańska-Grassowa, Warszawa 1970, s. 140-142 .

21 D. i Z. Benedyktynowicz, Symbolika domu w tradycji ludowej, „Konteksty. Polska Sztuka Ludowa” 1990 , nr 3, s. 51. 
zmarłych. Granicą symboliczną dla mieszkańców „wioski etnograficznej”, którzy praktycznie przez całe życie nie opuszczają bezpośredniego sąsiedztwa wsi, jest także rozstaj dróg, które wiodą do orbis exterior. Postacie, które przynoszą wieści z szerokiego świata lub odgrywają takie postaci (kolędnicy), są traktowane w kulturze ludowej jako przekraczający symboliczną granicę pomiędzy „tym” a „tamtym” światem ${ }^{22}$.

Co ciekawe, granice w krajobrazie kulturowym także wpisują się w jego temporalność. W niektóre pory roku lub dni w kalendarzu obrzędowym granice pojawiają się lub znikają. W Irlandii w dzień Samhain, czyli celtyckiego święta zmarłych, wejścia do kurhanów, jaskiń, a nawet dziuple w drzewach stają się bramą do krainy zmarłych, granicą, którą można tego dnia przekroczyć w obie strony ${ }^{23}$.

Symboliczne granice w krajobrazie kulturowym oddzielają obszary sacrum od obszarów profanum. Klasyczna dychotomia u Eliadego jest nie tylko oddzieleniem różnych sfer w przestrzeni, ale także odmiennym sposobem bycia $w$ świecie ${ }^{24}$. Homo religiosus będzie inaczej interpretował symbolikę przestrzeni niż człowiek niereligijny. Można zatem powiedzieć, że dla człowieka świeckiego i dla człowieka religijnego ta sama przestrzeń będzie miała zupełnie inne znaczenie: dla pierwszego będzie homogeniczna i pozbawiona symboliki, dla drugiego będzie heterogeniczna i przesiąknięta wymiarem duchowym. Przestrzeń sakralna jest zarazem przyczynkiem do ustanowienia pewnego porządku w świecie, do ukonstytuowania centrum, gradacji znaczenia, a nawet organizacji czasu. Przy czym, jak zaznacza Eliade, doskonale świecka egzystencja nie istnieje $e^{25}$, człowiek nie może uwolnić się całkowicie od schematów myślenia religijnego, a zatem zawsze będą istniały takie przestrzenie, obiekty i miejsca w krajobrazie, gdzie będzie odczuwał hierofanię czy - jak nazwałby to wrażenie Rudolf Otto - odczucie numinotyczne $e^{26}$.

Omawiane powyżej przykłady dotyczą skali małej społeczności lokalnej, klasycznej „wioski etnograficznej”. Przez krajobraz kulturowy przechodzą jednak także znacznie grubsze i dłuższe linie podziału, które dotyczą zarówno mikroskali społeczności lokalnej, jak i makroskali kontynentu i globu. Norman Davies pisze, że turysta, przechodząc przez most na Dunaju z Budy do Pesztu, przekracza jedną z silniej zakorzenionych w kulturze europejskiej granic pomiędzy Imperium a Barbaricum, czyli pomiędzy światem rzymskiej cywilizacji a światem europejskich barbarzyńców ${ }^{27}$. Kolejnymi ważnymi granicami na Starym Kontynencie są podziały pomiędzy chrześcijaństwem wschodnim i zachodnim czy dawna żelazna kurtyna. Przekraczając wschodnią granicę

22 Por. T. Baraniuk, Prześmiewanie świata. O przebierańcach zapustnych na pótnocno-wschodnim Mazowszu, Warszawa 1999.

23 W.Y. Evans-Wentz, The Fairy-Faith in Celtic Countries, London 1911, s. 291.

24 M. Eliade, Sacrum i profanum..., s. 10.

25 Tamże, s. 17.

26 R. Otto, Świętość. Elementy racjonalne i irracjonalne w pojęciu bóstwa, przeł. B. Kupis, Warszawa 1999. Doświadczeniem numinosum Otto określił to odczucie, które napawa człowieka strachem i zachwytem (misterium tremendum i misterium fascinans), jednocześnie mając w sobie coś niecodziennego i sakralnego.

27 N. Davies, Europa między Wschodem a Zachodem, przeł. B. Pietrzyk, Kraków 2007, s. 13-27. 
Polski, zmieniamy otoczenie, architekturę, kalendarz; przekraczając granice dawnego bloku wschodniego, widać zmianę w układzie urbanistycznym, typie zabudowy, a także w zachowaniach i przyzwyczajeniach ludzkich. Podobnie trwałe są historyczne granice państwowe, na przykład w Polsce granice pomiędzy dawnymi zaborami.

Granica w krajobrazie kulturowym funkcjonuje najczęściej w kontekście jej przekraczania. Termin liminalność (ang. liminality) pojawia się w literaturze antropologicznej przede wszystkim w odniesieniu do rytuałów przejścia (rites depassage ${ }^{28}$. Człowiek, przechodząc granicę, symbolicznie wychodzi z jednego stanu (w niektórych obrzędach wręcz umiera), przez chwilę znajduje się w stanie liminalnym, a zatem w fazie zawieszenia, w kulturowym no man's land, po to, by ostatecznie wejść w nową rzeczywistość, z powrotem „narodzić się" dla nowego porządku. Klasycznym przykładem są rytuały inicjacyjne, np. te, w trakcie których chłopiec staje się mężczyzną. Granica w krajobrazie kulturowym jest takim „miejscem liminalnym”, które nie podlega prawom żadnej z dwóch sfer - stąd rozstaje dróg, miedze lub brzegi rzek miały często charakter demoniczny.

\section{„WIOSKA ETNOGRAFICZNA” I „GLOBALNA WIOSKA”}

Przedstawiona powyżej rola granic w krajobrazie kulturowym dotyczy społeczeństwa tradycyjnego. Mikroświat „wioski etnograficznej” był pełen symbolicznych linii podziału, a wyobraźnia ludowa utrwalona wielowiekową tradycją wpisała te konotacje trwale w kulturę lokalną. W zglobalizowanym świecie ta symbolika jest może osłabiona i mniej widoczna, choć bywa tak głęboko osadzona w kulturze, że z powodzeniem żyje w podświadomości także dziś - zakodowana w przesądach, zachowaniach i obrzędach.

Wydaje się, że rewolucja komunikacyjna i technologiczna drugiej połowy XX stulecia przekreśliła ten symboliczny wymiar przekraczania granic w krajobrazie kulturowym. Ludzie coraz mniej żyją lokalnie, a coraz bardziej globalnie - mają także globalną perspektywę, nieograniczoną do najbliższego rozstaja dróg. Tymczasem brak zakotwiczenia w żadnym lokalnym krajobrazie i ciągłe życie na walizkach sprawiają, że wielu obywateli „globalnej wioski” ma poczucie bycia w ciągłej fazie liminalnej ${ }^{29}$.

Autorem określenia "globalna wioska” był Marshall McLuhan. Po raz pierwszy użył go w wydanej w 1962 r. książce The Gutenberg Galaxy: The Making of Typographic $\operatorname{Man}^{30} \mathrm{w}$ kontekście globalnego zasięgu mediów i globalnego przepływu informacji. Jednak szeroki rozgłos pojęcie zyskało dopiero w czasach rozpowszechnienia Internetu w latach 90. Współczesne technologie informacyjne pozwalają na komunikowanie się ludzi na całym świecie w tempie zbliżonym, a nawet szybszym, do mieszkańców klasycznej „wioski etnograficznej”.

\footnotetext{
28 Por. przede wszystkim: A. van Gennep, Obrzędy przejścia. Systematyczne studium ceremonii: o bramie i progu, o gościnności i adopcji, przeł. B. Biały, wstępem opatrzyła J. Tokarska-Bakir, Warszawa 2006.

29 Por. A. Szakolczai, Permanent Liminality and Modernity, London 2016.

30 M. McLuhan, The Gutenberg Galaxy: The Making of Typographic Man, Toronto 1962.
} 
Podczas gdy w kulturze tradycyjnej „miejscem liminalnym” był rozstaj dróg, próg świątyni czy granica lasu, w świecie nowoczesnym podobną funkcję pełnią np. lotniska: przejście odprawy „zamyka” fazę pobytu w miejscu A, okres oczekiwania na lot oraz sam lot określa fazę liminalną, wreszcie przejście bramki w miejscu docelowym to początek fazy pobytu w miejscu $B$.

Liminalną rolę odgrywa nie tylko miejsce, ale i czas - ostatnio popularny staje się tak zwany gap year, czyli rok przerwy pomiędzy szkołą a studiami bądź pracą zawodową, kiedy to młody człowiek jeździ po świecie, pracuje, realizuje projekty wolontariatu - po to, by wejść w dorosłość.

W świecie wirtualnym również występują granice, sfery i „punkty światła”. Przestrzeń wirtualna jest typem przestrzeni społecznej, gdzie ludzie uczestniczą (bo nie spotykają się realnie) w wymianie informacji ${ }^{31}$. Podobnie jak klasyczny krajobraz ma ona również wymiar indywidualny i społeczny: są strony internetowe, portale społecznościowe czy gry, które człowiek „odkrywa” samemu, poznając ich narracje; są też takie, które budują społeczności, a zatem narracje są w dużej mierze uwspólnione. „Cyberkrajobraz" staje się coraz bardziej równoległy do tego, w którym ludzie funkcjonują w świecie realnym. I rzeczywiście, „globalna wioska” wydaje się dziś zbyt duża, żeby tworzyła jeden zwarty krajobraz, gdzie każdy kamień i drzewo ma swoją narrację. Stąd w zglobalizowanym świecie krajobrazy mają charakter kolażowy, są wielostanowiskowe, często łącząc miejsca i przestrzenie znacznie od siebie oddalone.

\section{KRAJOBRAZ WIELOSTANOWISKOWY}

Przez długie lata antropologia kulturowa była uwiązana właśnie tą „wioską etnograficzną": badania były skoncentrowane w określonym miejscu i czasie, obejmowały precyzyjnie zdefiniowaną grupę, opierały się na wywiadach etnograficznych i obserwacji uczestniczącej in situ, starały się przedstawić jak najwięcej kontekstu samego wywiadu, badały struktury kulturowe ${ }^{32}$.

Wraz z globalizacją i nową epoką w technologii (a zwłaszcza wraz z rewolucją informatyczną, czyli pojawieniem się Internetu, telewizji satelitarnej, telefonów komórkowych itp.), zmieniły się drastycznie warunki badań etnograficznych (oczywiście nie wszędzie i nie w równym stopniu). „Wioska etnograficzna” przestała istnieć, ponieważ ludzie zaczęli częściej migrować, a do „wioski” poprzez telewizję i komputery weszła kultura globalna ${ }^{33}$. Etnografia powoli odchodzi od klasycznych tematów, takich jak religia, pokrewieństwo, rytuał, na rzecz takich zagadnień jak etnografia procesów

31 U. Myga-Piątek, $O$ wzajemnych relacjach przestrzeni i krajobrazu kulturowego: rozważania wstępne, „Prace Komisji Krajobrazu Kulturowego” 2014, nr 24, s. 40.

32 G.E. Marcus, Ethnography in/of the World System. The Emergence of Multi-Sited Ethnography, „Annual Review of Anthropology" 1995, vol. 24, s. 95-117.

33 Por. P. Levitt, The Transnational Villagers, Los Angeles 2001. Autorka opisuje tam społeczność migrantów z Republiki Dominikany żyjącą w Bostonie. Ich relacje z ziemią ojczystą wpływają zarówno na samych migrantów, jak i na społeczność, która została na Dominikanie. 
społecznych, etnografia sieci. Granice fizyczne stały się mniej istotne niż granice społeczne - a tych nie można badać inaczej niż w makroskali.

Wiedza uzyskana dzięki klasycznej metodzie etnograficznej stała się bardzo fragmentaryczna, bo nie uwzględniała np. wpływu migrantów zarobkowych na kulturę „wioski”34. Etnografia, jak każda dziedzina nauki, stara się jak najlepiej opisać zastaną rzeczywistość, dlatego sięga do wszelkich dostępnych źródeł wiedzy o niej. To desperackie poszukiwanie holizmu poznawczego skutkuje tym, że w dzisiejszym świecie często potrzebne są badania w co najmniej dwóch lub więcej miejscach.

Jako przykład zawodności tradycyjnej etnografii w dzisiejszych czasach mogą posłużyć badania, które przeprowadził Matei Candea w wiosce Crucetta na Korsyce ${ }^{35}$. Badacz pojechał tam jako świeżo upieczony magister etnografii z zamiarem badania społecznej integracji w wiosce na północy wyspy. Na miejscu okazało się, że klasyczne badania są wręcz niemożliwe, ponieważ połowa mieszkańców stale dojeżdża do pracy na drugi koniec wyspy, więzi lokalne zostały w dużej mierze zastąpione przez więzi ponadregionalne, a wszyscy młodzi mieszkają, pracują bądź studiują w Paryżu, Lyonie lub Marsylii.

Przyczyną zmiany podejścia $\mathrm{z}$ „wioskowego” na „wielostanowiskowe” jest zatem, oprócz globalizacji, próba poszukiwania możliwie holistycznego opisu rzeczywistości, zmiana struktur społecznych (np. silniejsze więzy symboliczne łączą często pracowników jednej korporacji niż sąsiadów z jednej wioski), mobilność społeczna i terytorialna, zatarcie granic terytorialnych i przeniesienie ciężaru na granice społeczne.

Etnografia wielostanowiskowa pozwala na bardziej interdyscyplinarne i międzynarodowe badania (zwłaszcza w sytuacjach migracyjnych), wykorzystuje nowe technologie (Internet), jest zorientowana na śledzenie procesów (kultura nigdy nie jest „wyspą”). Badani często sami są badaczami - angażują się w przeprowadzenie badań w swoim miejscu zamieszkania, w swoim kontekście społecznym ${ }^{36}$. Pozwala to na objęcie badaniami znacznie większych grup, a także na pewną łatwość doboru rozmówców, na jaką może sobie pozwolić osoba będąca „w środku”.

Etnografia wielostanowiskowa bada sieci, a nie stanowiska, polega na podążaniu za ludźmi, problemami, ideami, opowieściami. Jest to zatem etnografia „w ruchu”, podobnie jak w ruchu są społeczeństwa w zglobalizowanym świecie. Badania są przekrojowe, a nie opisowe. Liczą się powiązania społeczne, symboliczne i tożsamościowe, a nie terytorialne.

To podejście nie jest jednak wolne od wad. Badacz nie może się pozbyć wrażenia niekompletności, niedoskonałości i fragmentaryczności wyników badań. Jednoczesne współistnienie tak wielu kontekstów badawczych powoduje, że człowiek nie jest w stanie objąć ich wszystkich umysłem. Dużo łatwiej ująć kontekst (społeczny, przestrzenny,

34 Tamże.

35 M. Candea, Arbitrary Locations: In Defence of the Bounded Field-site, [w:] Multi-sited Ethnography: Theory, Praxis and Locality in Contemporary Research, red. M.A. Falzon, London 2009, s. 25-45.

36 C. Horst, Expanding Sites: The Question of Depth Explored, [w:] Multi-sited Ethnography: Theory, Praxis and Locality in Contemporary Research, red. M.A. Falzon, London 2009, s. 119-133. 
kulturowy) w monograficznym opisie „wioski etnograficznej”. W przekrojowych badaniach wielostanowiskowych konteksty są często tak wielowątkowe i rozmyte, że monograficzne ich ujęcie jest po prostu niemożliwe. Poprzez rozmycie kontekstu gubimy „gęstość" opisu, nie można też tych opisów porównywać ${ }^{37}$. Często może się także okazać, że globalna sieć czy proces, któremu się przyglądamy, po prostu nie istnieje.

Niemniej jednak etnografia wielostanowiskowa okazuje się współcześnie jedynym wyjściem, ponieważ sam badany stał się wielostanowiskowy. Podobnie jego krajobraz kulturowy. Odległość przestaje odgrywać tak wielką rolę, granice krajobrazu odrywają się od miejsca wychowania, wkraczają w nowe kraje, czasem też w rzeczywistość wirtualną. Często ludzie łączą życie jednocześnie w dwóch oddalonych o tysiące kilometrów miejscach, dzieląc swój krajobraz kulturowy. Coraz częściej „obywatele świata” w ogóle rozciągają krajobraz kulturowy praktycznie na cały świat, gdyż żyją po trochu w wielu miastach, krajach czy kontynentach. Wówczas ich globalny krajobraz kulturowy przypomina sieć połączonych ze sobą „punktów światła” rozmieszczonych na terenie całej Ziemi.

\section{„BLISKO-DALEKO”}

Kategoria „blisko-daleko” jest niezwykle ciekawa w kontekście antropologicznej refleksji nad liminalnością krajobrazu kulturowego. Semantyka tych określeń jest bardzo indywidualna. To, co dla kogoś jest „blisko”, dla kogoś innego będzie „daleko”. Jednocześnie to indywidualne doświadczenie jest uwarunkowane społecznie, a nawet politycznie ${ }^{38}$. Granica pomiędzy tymi sferami przesunęła się wraz z rozwojem środków transportu. Podobnie zmienia się wraz z wiekiem każdej jednostki i etapem życia, w jakim się ona znajduje.

Dla dziecka „daleko” jest w zasadzie wszędzie, ponieważ ma bardzo ograniczone pole samodzielnego przemieszczania się („blisko” jest tam, gdzie może samo pójść pod okiem opiekunów, „daleko” tam, gdzie zabraniają mu iść samemu). Wraz z wiekiem zwiększa się zakres miejsc, do których możemy samodzielnie dotrzeć. W końcu, przy pełnej samodzielności, pojawiają się zupełnie inne ograniczenia: finansowe, rodzinne, polityczne. W starszym wieku znów z kolei „daleko” zaczyna być niemal wszystko, co jest poza mieszkaniem, ponieważ wiek lub choroba ponownie ograniczają możliwość przemieszczania się.

Semantyka „blisko” i „daleko” jest kwestią indywidualną, co wynika z wychowania, doświadczeń życiowych, możliwości finansowych, edukacji, środowiska, uwarunkowań politycznych. Przez osoby, które dużo i daleko podróżują, przestrzeń jest inaczej odbierana niż w przypadku osób, które w życiu podróżowały rzadko i na niewielkie odległości.

W ujęciu historycznym „blisko-daleko” także było kwestią bardzo indywidualną. Inaczej odbieral ją uwiązany do ziemi przez system feudalny chłop, który tam się

37 Przez co etnografia de facto przestaje być etnologią.

38 Por. L. Moczulski, Geopolityka. Potega w czasie i przestrzeni, Warszawa 2010. 
urodził, żył i umarł, a inaczej Mikołaj Kopernik, który studiował we Włoszech, czytał o odkryciu nowej drogi do Indii i opisywał Kosmos.

Prowadząc badania nad rzeczywistością przedwojennego galicyjskiego sztetla ${ }^{39}$, miałem do czynienia z sytuacją ograniczenia niemal całej aktywności społeczno-ekonomicznej mieszkańców do rzeczywistości małego miasteczka i jego okolic jeszcze w latach 30. XX wieku. Wieloetniczna społeczność była praktycznie samowystarczalna, życie wyznaczał cykliczny taskscape: targi, święta religijne (różnych religii), święta narodowe ${ }^{40}$. Krajobraz był zatem bardzo ograniczony terytorialnie, a zarazem niezwykle „nasycony” symbolicznie, poprzez bagaż narracji o każdym miejscu czy obiekcie, który krążył w tradycji ustnej lokalnej społeczności. Średniowieczne pojęcie „blisko” w realiach prowincjonalnych przetrwało do dziś w niektórych miejscach na świecie, podobnie klasyczna „wioska etnograficzna”.

Kategoria „blisko-daleko” wiązała się zatem z łatwością transportu. Dla starożytnych Greków „blisko” była Marsylia czy Teby, ale „daleko” Illiria, która geograficznie leży o wiele bliżej Grecji niż Galia. Światem Greków był jednak basen Morza Sródziemnego, miejsca dostępne dla statków; wszystko, co było w głębi lądu, było niedostępne i dalekie, zamieszkane przez mityczne stwory i groźne. Dla Rzymian, którzy podbili te tereny (Galię, Germanię, Illirię, Trację) i połączyli je systemem dobrych dróg, Dunaj i Ren nie wydawały się już tak „dalekie”.

Współczesny postęp technologiczny i komunikacyjny sprawił, że „blisko” są miejsca nieraz bardzo odległe, ale np. posiadające duże lotniska przesiadkowe („huby”), choćby Dubaj, Frankfurt, Londyn. Rzeczywiście dużo łatwiej i szybciej (a czasem nawet taniej!) dolecieć z Warszawy do Londynu, niż dojechać np. do Suwałk, przez co de facto Londyn jest w odczuciu indywidualnym „bliżej”.

W sytuacjach migracyjnych zacierają się pojęcia „blisko” i „daleko” - podwójna rzeczywistość, w której się żyje, sprawia, że nawet podróż (mimo że trwa dokładnie tyle samo) wydaje się z czasem o wiele krótsza niż za pierwszym razem.

Dla większości Polaków w 2004 r. (a jeszcze bardziej w 2007 r., czyli od wstąpienia do strefy Schengen) Europa stała się „bliższa”. Portugalia wydaje się znacznie bardziej dostępna niż położona 150 kilometrów od Warszawy Białoruś. Podobnie Syria wydaje się dużo „dalej” niż położony fizycznie dalej Izrael (nie tylko dlatego, że trwa tam wojna, ale także dlatego, że do Izraela jest obecnie mnóstwo tanich lotów). Niektóre miejsca na mapie politycznej świata wydają się „dalej” ze względów politycznych: trudności wizowych, bezpieczeństwa, skomunikowania, kultury.

Dla kategorii „blisko-daleko” podstawowym kryterium jest dostępność danego miejsca: czy jest „w zasięgu naszych możliwości”. Im większe są bariery w dostępie do danego miejsca (finansowe, społeczne, polityczne), tym bardziej to miejsce jest w naszej świadomości „daleko”. Odnosi się to zarówno do realiów historycznych (dla

39 Zdrobnienie od jid. „shtot”, miasto. Sztetlem określa się z reguły wielokulturowe miasteczko w przedwojennej Europie Środkowo-Wschodniej widziane z żydowskiej perspektywy.

40 W. Bedyński, Podkarpathian Shtetl, [w:] Integrating Minorities. Traditional Communities and Modernization, red. L. Peti i A. Barszczewska, Kluż 2011, s. 57-101. 
pańszczyźnianego chłopa Kraków był „daleko” nie dlatego, że fizycznie nie był w stanie tam dojść, ale dlatego, że system feudalny trzymał go w jego wsi), jak i do realiów współczesnych (po wejściu Polski do UE „daleka” Hiszpania stała się „bliska”, a przynajmniej bliższa niż kiedyś była RFN).

Kategoria „blisko-daleko” jest jedną z ciekawszych granic w krajobrazie kulturowym. Uwidacznia jego indywidualny i społeczny charakter - umiejscowienie tej granicy jest bardzo subiektywne, a jednocześnie zależne od czynników społecznych, politycznych, ekonomicznych itd.

\section{KRAJOBRAZ KULTUROWY W DOŚWIADCZENIU POKOLENIOWYM}

Tim Ingold wiąże krajobraz z czasem, tezą artykułu jest temporalność zjawiska krajobrazu kulturowego ${ }^{41}$. Jest on procesem zarówno w życiu danej jednostki, jak i w trwaniu społecznym. W doświadczeniu jednostkowym przejawia się poprzez organizację zadań, cykl aktywności dobowych, rocznych, związanych z pracą lub wypoczynkiem (taskscape). Temporalność krajobrazu kulturowego przejawia się także w kontekście pokoleniowym - można mówić o swoistym generationscape. $\mathrm{Z}$ wywiadów biograficznych przeprowadzonych przeze mnie na Podkarpaciu i na Mazurach ${ }^{42}$ wynikają pewne charakterystyczne cechy konstrukcji krajobrazu poszczególnych pokoleń żyjących współcześnie Polaków:

Pokolenie wojny - krajobraz sentymentalny. Najstarsze pokolenie cechuje gloryfikacja rzeczywistości przedwojennej, próba powrotu pamięcią do miejsc wychowania; narracja o krajobrazie zabarwiona jest romantyzmem w stylu XIX-wiecznym, częstym motywem jest nostalgia za kresami, czyli utraconą krainą dzieciństwa, która przez dziesięciolecia była „daleko” ze względów politycznych, a teraz jest „daleko” ze względu na wiek.

Pokolenie PRL - krajobraz wyparty. Ludzie urodzeni w latach 50. i 60. nie wspominają krajobrazu swojego dzieciństwa, rzadko dzielą się z młodszym pokoleniem informacjami na ten temat; żyją raczej krajobrazem po zmianie '89 i z tego są dumni, jako że to oni byli autorami tej zmiany. Ale jest to krajobraz polski, lokalny, sąsiedzki. Bardzo często po przełomie, kiedy mogli wyjechać, nie zrobili tego, ponieważ mieli już ustabilizowaną społeczną pozycję w miejscu zamieszkania. Mają jednak świadomość nowych możliwości, do których przekonują swoje dzieci, wypychając je w świat. Często realizują siebie poprzez zapewnienie dzieciom jak najlepszego startu w świecie nowych możliwości.

Pokolenie wolności - krajobraz rozproszony. Młodzi ludzie urodzeni w latach 80. z doświadczeniem migracyjnym. Żyją w dwóch światach: mają w głowie krajobraz

\footnotetext{
T. Ingold, The Temporality..., s. 157.

42 Badania na Podkarpaciu dotyczące pamięci o życiu w społeczeństwie wielokulturowym sztetla, prowadzone w latach 2004-2008; badania na Mazurach dotyczące mobilności w ujęciu terytorialnym i społecznym mieszkańców małego miasta na przykładzie Giżycka, prowadzone od 2017 roku.
} 
dzieciństwa, mikroświat, w którym wzrastali. Pamiętają świat bez Internetu i komórek, więc mają jeszcze zakodowane doświadczenie lokalności, układów sąsiedzkich lub szkolno-podwórkowych. Cenią sobie wagę bezpośrednich relacji „na żywo” z innymi ludźmi, stąd często chodzą na imprezy, spotkania, zajęcia sportowe. Pamiętają też jak przez mgłę PRL i sytuację transformacji, którą jednak nieco mitologizują, ponieważ patrzyli na nią oczami dziecka. Charakterystyczny dla tego pokolenia jest pęd do migracji. Po edukacji (która zazwyczaj przyszła im łatwiej niż rodzicom) nie byli uwiązani układami społecznymi i ustabilizowaną sytuacją życiową, przez co mogli wyjechać - na studia, staż lub od razu do pracy. Często zostali „tam” na dłużej. Mają znacznie poszerzony horyzont krajobrazu. Pokolenie to cechuje wczesna samodzielność i późne „wyjście z domu". W sytuacjach migracyjnych muszą szybko się usamodzielnić, często dość wcześnie mieszkają sami, lecz wracając do rodzinnej miejscowości, wracają do sytuacji sprzed wyjazdu, do pierwotnych układów rodzinnych, sąsiedzkich, lokalnych. Łączą w sobie dwa krajobrazy: „mikro-krajobraz” rodzinnej miejscowości i realiów wychowania w lokalności oraz „makro-krajobraz” wielkiego świata lub miejsca docelowego migracji. Mobilność jest dla nich przepisem na szczęście.

Pokolenie IT - krajobraz wirtualny. Ludzie urodzeni po połowie lat 90., którzy nie znają rzeczywistości bez Internetu, telewizji satelitarnej itp. Praktycznie nie mają doświadczenia życia lokalnie. Od początku uczestniczyli w kulturze globalnej, kontaktowali się z całym światem - często nawet nieświadomie. Paradoksalnie cechuje ich mniejsza mobilność niż ich starszych kolegów z pokolenia lat 80., ponieważ globalny świat wirtualny jest często substytutem wyjazdów. Nie mają również takiego „głodu wyjazdów", nie są też do nich tak dopingowani przez starszych, jak pokolenie lat 80 . Później się usamodzielniają (są np. dowożeni do szkoły przez nadopiekuńczych rodziców - lub po prostu przez rodziców, którzy w międzyczasie dorobili się samochodu). Możliwość wyjazdów jest dla nich tak oczywista, że samo jeżdżenie nie jest tak atrakcyjne, jak dla starszych. Łatwość przemieszczania się i możliwość życia gdzie indziej nie jest już żadnym „odkryciem”.

\section{WNIOSKI}

Krajobraz kulturowy podlega zmianom równoległym i analogicznym do zmian zachodzących w kulturze ${ }^{43}$. Beata Frydryczak przypomina pojawiające się już w latach 90. hasła „śmierci natury” lub „śmierci krajobrazu”“4 . Krajobraz miałby podlegać postępującej hybrydyzacji, a doświadczenie topograficzne miałoby zostać zastąpione doświadczeniem topologicznym.

Wydaje mi się, że ogłaszanie śmierci krajobrazu kulturowego i rozerwania jego odwiecznych więzi z naturą jest pewną przesadą, jednak zdecydowanie w postmodernistycznej kulturze i w świecie informatycznym krajobraz, podobnie jak kultura, podlega

43 B. Frydryczak, $O$ zakotwiczeniu..., s. 161.

44 Tamże. 
daleko idącym zmianom. Tradycyjne ujęcie krajobrazu znanego nam z „wioski etnograficznej", ograniczonego terytorialnie i symbolicznie, traci definitywnie aktualność, zwłaszcza w młodym pokoleniu, żyjącym globalnie i mającym także globalny krajobraz, częściowo istniejący w świecie wirtualnym. Odległość przestaje mieć znaczenie, liczy się jedynie dostępność - głównie finansowa; a także czas: dawniej powtarzalny, cykliczny i naturalny, obecnie dramatycznie rozpędzony i linearny.

Niemniej jednak krajobraz kulturowy zachował dwie cechy, które opisał Ingold w swoim artykule: nadal ma wymiar indywidualny i społeczny, i nadal jest stale „w procesie". Przesuwanie się ludzkości w stronę kultury, dążenie do estetyzacji świata natury, urbanizacja, rewolucja komunikacyjna i życie w rzeczywistości wirtualnej tego nie zmieniły. Frydryczak wyraża nadzieję, że krajobraz kulturowy w świecie pozbawionym natury będzie remedium na szaleństwo postmodernistycznego świata.

\section{BIBLIOGRAFIA}

Assman J., Communicative and Cultural Memory, [w:] Cultural Memory Studies: An International and Interdisciplinary Handbook, red. A. Erll i A. Nünning, Berlin-New York 2008.

Banaszczyk T., Czas jako kategoria spoteczna: wstępne rozważania socjologiczne o czasie, Wrocław 1981.

Baraniuk T., Prześmiewanie świata. O przebierańcach zapustnych na pótnocno-wschodnim Mazowszu, Warszawa 1999.

Bedyński W., Podkarpathian Shtetl, [w:] Integrating Minorities. Traditional Communities and Modernization, red. L. Peti i A. Barszczewska, Kluż 2011.

Benedyktynowicz D. i Z., Symbolika domu w tradycji ludowej, „Konteksty. Polska Sztuka Ludowa" 1990, nr 3.

Braudel F., Gramatyka cywilizacji, przeł. H. Igalson-Tygielska, Warszawa 2006.

Braudel F., Morze Śródziemne i świat śródziemnomorski w epoce Filipa II, przeł. M. Ochab i T. Mrówczyński, Gdańsk 1976.

Candea M., Arbitrary Locations: in Defence of the Bounded Field-site, [w:] Multi-sited Ethnography: Theory, Praxis and Locality in Contemporary Research, red. M.A. Falzon, London 2009, https://doi.org/10.1111/j.1467-9655.2007.00419.x.

Chatwin B., The Songlines, London 1987.

Davies N., Europa między Wschodem a Zachodem, przeł. B. Pietrzyk, Kraków 2007.

Durkheim E., Opodziale pracy spotecznej, przet. K. Wakar, Warszawa 2011.

Eliade M., Sacrum i profanum. O istocie religijności, przel. R. Reszke, Kraków 1996.

Evans-Wentz W.Y., The Fairy-Faith in Celtic Countries, London 1911.

Frydryczak B., O zakotwiczeniu krajobrazu w kulturze, „Prace Kulturoznawcze” 2013, t. 15.

Gennep A. van, Obrzędy przejścia. Systematyczne studium ceremonii: o bramie i progu, o gościnności i adopcji, przeł. B. Biały, wstępem opatrzyła J. Tokarska-Bakir, Warszawa 2006.

Horst C., Expanding Sites: the Question of Depth Explored, [w:] Multi-sited Ethnography: Theory, Praxis and Locality in Contemporary Research, red. M.A. Falzon, London 2009. 
Ingold T., The Temporality of the Landscape, „World Archeology” 1993, vol. 25, nr 2, https:// doi.org/10.1080/00438243.1993.9980235.

Le Goff J., Kultura średniowiecznej Europy, przeł. H. Szumańska-Grassowa, Warszawa 1970.

Levitt P., The Transnational Villagers, Los Angeles 2001.

Marcus G.E., Ethnography in/of the World System. The Emergence of Multi-Sited Ethnography, „Annual Review of Anthropology” 1995, nr 24, https://doi.org/10.1146/annurev. an.24.100195.000523.

McLuhan M., The Gutenberg Galaxy: The Making of Typographic Man, Toronto 1962.

Meining D.W., The Interpretation of Ordinary Landscapes, New York 1979.

Moczulski L., Geopolityka. Potega w czasie i przestrzeni, Warszawa 2010.

Myga-Piątek U., O wzajemnych relacjach przestrzeni i krajobrazu kulturowego: rozważania wstępne, „Prace Komisji Krajobrazu Kulturowego” 2014, nr 24.

Myga-Piątek U., Pamięć krajobrazu - zapis dziejów w przestrzeni, „Studia Geohistorica” 2015, nr 3.

Otto R., Świętość. Elementy racjonalne i irracjonalne w pojęciu bóstwa, przeł. B. Kupis, Warszawa 1999.

Pietraszko S., Krajobraz i kultura, [w:] Kultura. Studia teoretyczne i metodologiczne, red. S. Pietraszko, Wrocław 2012.

Saussure F. de, Kurs językoznawstwa ogólnego, przeł. K. Kasprzyk, wstęp. W. Doroszewski, Warszawa 1961.

Sołżenicyn A., Archipelag GUŁag 1918-1956, przeł. J. Pomianowski, Poznań 2008.

Szakolczai A., Permanent Liminality and Modernity, London 2016.

Szyjewski A., Mitologia australijska jako nośnik tożsamości, Kraków 2014.

Dr Wojciech BEDYŃSKI - adiunkt w Ośrodku Badań nad Migracjami Uniwersytetu Warszawskiego. Absolwent Instytutu Etnologii i Antropologii Kultury tegoż uniwersytetu oraz Sorbony (Paris-IV), historyk i antropolog. Autor i redaktor kilku książek oraz artykułów z zakresu antropologii krajobrazu, pamięci o życiu w społeczeństwie wielokulturowym na przedwojennym Podkarpaciu, chrystianizacji Irlandii i kultury celtyckiej. Obecnie w ramach projektu Narodowego Centrum Nauki zajmuje się badaniami nad mobilnością terytorialną i społeczną w kontekście małego miasta na przykładzie Giżycka. 